Wahana Didaktika Vol. 18 No.2 Mei 2020 : 112-119

\title{
PENGARUH MODEL PEMBELAJARAN KOOPERATIF TIPE JIGSAW TERHADAP HASIL BELAJAR EKONOMI SMA N 20 PALEMBANG
}

\author{
Oleh: Selly Parela, ErmaYulaini, M.Toyib \\ (Universitas PGRI Palembang) \\ Email: sellyparela01@gmail.com
}

\begin{abstract}
Abstrak
Tujuan dari penelitian ini untuk mengetahui pengaruh model pembelajaran kooperatif tipe jigsaw terhadap hasil belajar ekonomi di SMA N 20 Palembang tahun pelajaran 2019/2020. Metode yang digunakan dalam penelitian ini adalah metode true ekperimental design. Teknik pengumpulan data dalam penelitian ini adalah observasi, dokumentasi, dan tes. Teknik analisis data dalam penelitian ini adalah regresi linier sederhana dengan dummy variabel dengan pengujian hipotesis menggunakan uji " $t$ " tes. Dari hasil penelitian kelas eksperimen yang diberi perlakuan model pembelajaran kooperatif tipe jigsaw lebih baik dari kelas kontrol yang diberi perlakuan model pembelajaran konvensional. Artinya terdapat pengaruh model pembelajaran kooperatif tipe jigsaw terhadap hasil belajar ekonomi di SMA N 20 Palembang tahun pelajaran 2019/2020.
\end{abstract}

Kata Kunci: Model Pembelajaran Kooperatif Tipe Jigsaw, Hasil Belajar

\section{THE EFFECT OF JIGSAW COOPERATIVE LEARNING MODEL ON ECONOMIC LEARNING OUTCOMES SMA N 20 PALEMBANG}

\begin{abstract}
The purpose of this study is to determine the effect of the jigsaw cooperative learning model on economic learning outcomes in SMA N 20 Palembang in the 2019/2020 academic year. The method used in this research is the true experimental design method. Data collection techniques used are documentation, observation and tests. The data analysis technique in this study is simple linear regression with dummy variables with hypothesis testing using the " $t$ " test. From the results of the experimental class research that is treated jigsaw cooperative learning model is better than the control class that is treated conventional learning model. This means that there is an influence of the type of jigsaw cooperative in learning model on economic learning outcomes in SMA N 20 Palembang in the academic year 2019/2020.
\end{abstract}

Keywords: Jigsaw Type Cooperative Learning Model, Learning Outcomes 


\section{A. PENDAHULUAN}

Hal-hal yang mempengaruhi hasil belajar, selain model pembelajaran karena salah satu tugas mengajar sendiri adalah untuk membimbing dan membantu siswa dalam belajar. Untuk itu, pendidik diharapkan dapat memilih model pembelajaran yang sesuai dengan kondisi siswa, kelas dan lingkungan tempat belajar, selain itu juga harus sesuai dengan tujuan pembelajaran.

Sebenarnya tidak ada model pembelajaran yang sempurna, setiap model pembelajaran yang digunakan pasti mempunyai kelebihan atau kelemahan. Oleh karena itu, Dengan penggunaan model pembelajaran kooperatif tipe jigsaw pada mata pelajaran ekonomi diharapkan tujuan yang dirumuskan dapat tercapai. Proses pembelajaran bisa dikatakan berhasil apabila terjadi perubahan positif dari peserta didik.

Berdasarkan informasi awal sebelum penelitian yang diperoleh peneliti bahwa pembelajaran IPS khususnya pada mata pelajaran ekonomi siswa masih kurang memahami atau mengerti karena selama ini proses belajar mengajar menggunakan model pembelajaran konvensional. Diharapkan melalui penerapan model pembelajaran kooperatif tipe jigsaw ini dapat meningkatkan keaktifan siswa dalam proses pembelajaran.

Hal yang membedakan model pembelajaran kooperatif tipe jigsaw dengan diskusi kelompok biasa adalah bahwa dalam model pembelajaran kooperatif tipe jigsaw masing-masing individu mempelajari bagian masing-masing dan kemudian bertukar dengan temannya sehingga akan terjadi ketergantungan positif antara siswa yang satu dengan yang lainnya hal ini diharapkan dapat meningkatkan hasil belajar siswa dan khususnya pada mata pelajaran ekonomi.

Berdasarkan uraian diatas, maka perumusan masalah yang akan dibahas pada penelitian ini adalah Apakah terdapat pengaruh model pembelajaran kooperatif tipe jigsaw terhadap hasil belajar ekonomi di SMA N 20 Palembang tahun pelajaran 2019/2020. 
Hamdayama (2015:87) "Model pembelajaran kooperatif tipe Jigsaw merupakan pembelajaran kooperatif, siswa belajar dalam kelompok kecil yang terdiri atas 4-5 orang dengan memperhatikan keheterogenan, bekerja sama positif dan setiap anggota bertanggung jawab untuk mempelajari masalah tertentu dari materi yang diberikan dan menyampaikan materi tersebut kepada anggota kelompok yang lain.

Rusman (2011:218) menyatakan bahwa Pelaksanaanya pengajaran kooperatif tipe Jigsaw dilakukan melalui langkah-langkah sebagai berikut:

a. Siswa dikelompokkan dengan anggota \pm 4 orang

b. Tiap orang dalam tim diberi materi dan tugas yang berbeda

c. Anggota dari tim yang berbeda dengan penugasan yang sama membentuk kelompok baru (kelompok ahli). Setelah kelompok ahli berdiskusi, tiap anggota kembali ke kelompok asal dan menjelaskan kepada anggota kelompok tentang subbab yang mereka kuasai

d. Tiap tim ahli mempresentasikan hasil diskusi

e. Pembahasan

f. Penutup

Hasil belajar merupakan suatu perubahan yang terjadi pada individu yang belajar bila seseorang telah belajar akan terjadi perubahan tingkah laku pada orang tersebut, misalnya dari tidak tahu menjadi tahu, dan dari tidak mengerti menjadi mengerti.

\section{B. METODOLOGI PENELITIAN}

Menurut Arikunto (2013:203), metode penelitian adalah cara yang digunakan oleh peneliti dalam mengumpulkan data penelitiannya. Dimaksud adalah angket, wawancara, pengamatan, atau observasi.

Metode penelitian yang digunakan dalam penelitian ini adalah metode true eksperimental design karena sampel yang digunakan untuk eksperimen dan kontrol diambil secara random dari populasi tertentu menurut Sugiyono 
Pengaruh Model Pembelajaran.... (Selly Parela, Erma Yulaini, M. Toyib)

(2015:112). Penelitian akan dilaksanakan di SMA N 20 Palembang yang berlokasi di Jl. TPH Sofyan Kenawas, Gandus, Kota Palembang.

Waktu dilaksanakan penelitian ini pada bulan Agustus sampai September 2019 dan yang menjadi sampel peneliti adalah peserta didik kelas X IPS 3 dan X IPS 4 semester ganjil tahun pelajaran 2019/2020.

Teknik pengumpulan data dalam penelitian ini yaitu dokumentasi, observasi dan tes. Dokumentasi digunakan untuk memperoleh data yang bersifat sekunder atau data sudah ada di sekolah antara lain untuk mengetahui hasil belajar siswa yang diperoleh dari hasil belajar siswa. Dalam penelitian ini dokumentasi digunakan untuk mengetahui data secara umum, misalnya mengenai jumlah siswa, jumlah guru, keadaan sekolah, dan sarana prasarana pembelajaran di SMA N 20 Palembang serta dokumen lain yang dibutuhkan.

Dalam penelitian ini observasi digunakan pada saat siswa mengikuti proses belajar mengajar yang sedang berlangsung yang bertujuan untuk melihat sikap atau keatifan siswa terhadap model pembelajaran yang diterapkan. Adapun aktivitas yang diamati adalah aktivitas visual, aktivitas lisan, aktivitas mendengarkan dan aktivitas menulis. Tes dilakukan bertujuan untuk mengetahui hasil belajar siswa pada mata pelajaran ekonomi. Bentuk tes yang dilakukan dalam penelitian ini adalah pilihan ganda dengan materi konsep dasar ilmu ekonomi.

\section{HASIL PENELITIAN DAN PEMBAHASAN}

Penelitian ini dilakukan di SMA N 20 Palembang pada tanggal 06 Agustus sampai dengan 07 September 2019 tahun pelajaran 2019/2020 dengan judul "pengaruh model pembelajaran kooperatif tipe jigsaw terhadap hasil belajar ekonomi”. Tujuan dari penelitian ini adalah untuk mengetahui pengaruh model pembelajaran kooperatif tipe jigsaw terhadap hasil belajar ekonomi di SMA N 20 Palembang tahun pelajaran 2019/2020. Pada penelitian ini materi yang diajarkan yaitu konsep dasar ilmu ekonomi adapun pengambilan data penelitian diperoleh 
dari data observasi, dokumentasi dan hasil tes. Sampel dalam penelitian ini adalah kelas X IPS 3 sebagai kelas eksperimen yang berjumlah 35 siswa yang diberi perlakuan dengan menerapkan model pembelajaran kooperatif tipe jigsaw dan kelas X IPS 4 sebagai kelas kontrol yang berjumlah 36 siswa yang diberi perlakuan dengan model pembelajaran konvensional.

Sebelum penelitian dilaksanakan peneliti terlebih dahulu mempersiapkan Rencana Pelaksanaan Pembelajaran (RPP) untuk kelas X IPS 3 sebagai kelas eksperimen yang diterapkan model pembelajaran kooperatif tipe jigsaw dan X IPS 4 sebagai kelas kontrol yang diterapkan model pembelajaran konvensional. Pembelajaran dilaksanakan sebanyak 2 kali pertemuan pada pertemuan terakhir diadakan tes untuk mengukur hasil belajar siswa di kelas eksperimen dan di kelas kontrol pada materi konsep dasar ilmu ekonomi dengan berupa 20 butir soal pilihan ganda dengan lima alternatif jawaban. Sebelum penelitian dilaksanakan, peneliti terlebih dahulu mempersiapkan Rencana Pelaksanaan Pembelajaran (RPP) untuk kelas eksperimen dan kelas kontrol.

\section{a. Deskripsi Hasil Observasi di Kelas Eksperimen}

Berdasarkan data distribusi frekuensi hasil observasi aktivitas belajar siswa kelas eksprimen, dapat dilihat bahwa dalam proses pembelajaran menggunakan model pembelajaran kooperatif tipe jigsaw siswa yang mencapai persentase sebesar 60,00 pada kriteria "Sangat Aktif" sebanyak 21 orang, kemudian siswa yang memperoleh persentase sebesar $25,71 \%$ pada kriteria “Aktif” sebanyak 9 orang dan siswa yang memperoleh persentase 8,57\% pada kriteria "Cukup Akitf" sebanyak 3 orang, sedangkan yang memperoleh persentase $5,71 \%$ pada kriteria "Kurang Aktif" sebanyak 2 orang. Rata-rata distribusi frekuensi hasil observasi aktivitas belajar siswa kelas eksperimen adalah 77,32 pada kriteria “Aktif”.

\section{b. Deskripsi Hasil Observasi di Kelas Kontrol}


Berdasarkan data distribusi frekuensi hasil observasi aktivitas belajar siswa kelas kontrol, dapat dilihat bahwa dalam proses pembelajaran menggunakan model pembelajaran konvensional siswa yang mencapai persentase sebesar 2,78\% pada kriteria “Sangat Aktif” sebanyak 1 orang, kemudian siswa yang memperoleh persentase sebesar 22,22\% pada kriteria “Aktif” sebanyak 8 orang dan siswa yang memperoleh persentase 36,11\% pada kriteria "Cukup Akitf” sebanyak 13 orang, sedangkan yang memperoleh presentase 27,78\% pada kriteria "Kurang Aktif" sebanyak 10 orang selanjutnya siswa yang memperoleh persentase $11,11 \%$ pada kriteria "Sangat Kurang Aktif" sebanyak 4 orang. Rata-rata distribusi frekuensi hasil observasi aktifivitas belajar kelas kontrol adalah 61,02 pada kriteria " Cukup Aktif".

\section{c. Deskripsi Hasil Belajar Siswa di Kelas Eksperimen}

Berdasarkan data distribusi frekuensi hasil belajar siswa kelas eksperimen, maka dapat dilihat bahwa dalam proses pembelajaran menggunakan model pembelajaran kooperatif tipe jigsaw siswa yang memperoleh nilai $86-100$ sebanyak 9 orang dengan persentase sebesar 25,71\% pada kriteria "Baik Sekali", kemudian siswa yang memperoleh nilai 71 - 85 sebanyak 19 orang dengan persentase sebesar 54,28\% pada kriteria "Baik" dan siswa yang memperoleh nilai 56-70 sebanyak 7 orang dengan persentase 20,00\% pada kriteria "Cukup" selanjutnya tidak ada siswa yang memperoleh nilai 41 - 45 / nilai kurang dari 40 pada kriteria "Kurang dan Kurang Sekali". Rata-rata hasil belajar kelas eksperimen adalah 80,71 .

\section{d. Deskripsi Hasil Belajar Siswa di Kelas Kontrol}

Berdasarkan data distribusi frekuensi hasil belajar siswa kelas kontrol, maka dapat dilihat bahwa dalam proses pembelajaran menggunkan model pembelajaran konvensional siswa yang memperoleh nilai 86 - 100 sebanyak 1 orang dengan persentase sebesar 2,77\% pada kriteria "Baik Sekali", kemudian siswa yang 
memperoleh nilai 71 - 85 sebanyak 13 orang dengan persentase sebesar $36,11 \%$ pada kriteria "Baik" dan siswa yang memperoleh nilai 56-70 sebanyak 20 orang dengan persentase 55,55\% pada kriteria "Cukup" selanjutnya siswa yang memperoleh nilai 41-55 sebanyak 2 orang dengan persentase 5,55\% dan tidak ada siswa yang memperoleh nilai kurang dari 40 pada kriteria "Kurang Sekali". Ratarata hasil belajar kelas kontrol adalah 70,00.

\section{PEMBAHASAN}

Berdasarkan hasil penelitian ini yang berjudul pengaruh model pembelajaran kooperatif tipe jigsaw terhadap hasil belajar ekonomi di SMA N 20 Palembang tahun pelajaran 2019/2020. Dimana pada proses pembelajaran di kelas X IPS 3 sebagai kelas eksperimen peneliti menggunakan model pembelajaran kooperatif tipe jigsaw. Menurut Hamdayama (2015:87) "Model pembelajaran kooperatif tipe jigsaw merupakan pembelajaran kooperatif, siswa belajar dalam kelompok kecil yang terdiri atas 4-5 orang dengan memperhatikan keheterogenan, bekerja sama positif dan setiap anggota bertanggung jawab untuk mempelajari masalah tertentu dari materi yang diberikan dan menyampaikan materi tersebut kepada anggota kelompok yang lain".

Kelebihan model pembelajaran kooperatif tipe jigsaw menurut Hamdayama (2015:89) yaitu (1) mempermudah pekerjaan guru dalam mengajar, karena sudah ada kelompok ahli yang bertugas menjelaskan materi kepada rekan- rekannya. (2) pemerataan penguasaan materi dapat dicapai dalam waktu yang lebih singkat. (3) metode pembelajaran ini dapat melatih siswa untuk lebih aktif dalam berbicara dan berpendapat. (4) apabila siswa tidak memiliki rasa percaya diri dalam berdiskusi menyampaikan materi kepada teman.

Dapat dilihat dari hasil rata-rata observasi aktivitas belajar siswa kelas eksperimen adalah 77,41 pada kriteria "Aktif”. Sedangkan dalam pelaksanaan proses pembelajaran di kelas control rata-rata observasi aktivitas belajar siswa kelas kontrol adalah 61,02 pada kriteria "Cukup Aktif”. Pada hasil observasi 
aktivitas belajar siswa pada kelas eksperimen yang menggunakan model pembelajaran kooperatif tipe jigsaw siswa dapat lebih aktif dalam proses pembelajaran dan berpengaruh terhadap hasil belajar siswa. Hal ini dapat menunjukkan bahwa nilai rata-rata tes hasil belajar siswa pada kelas ekperimen dengan nilai rata-rata $80,71 \%$.

Hal ini semakin menguatkan dengan adanya kajian teori yang mendukung. Berdasarkan penelitian yang dilakukan oleh peneliti diperoleh nilai thitung = 4,734 > dari tabel $=1,995$ berarti tolak $\mathrm{H}_{o}$ dan terima $\mathrm{H}_{\alpha}$ maka hipotesis penelitian berbunyi terdapat pengaruh model pembelajaran kooperatif tipe jigsaw terhadap hasil belajar ekonomi di SMA Negeri 20 Palembang.

\section{SIMPULAN}

Berdasarkan hasil penelitian maka dapat disimpulkan bahwa terdapat pengaruh model pembelajaran kooperatif tipe jigsaw terhadap hasil belajar ekonomi di SMA N 20 Palembang tahun pelajaran 2019/2020. Dengan koefisien determinasi pada kategori "Rendah" sebesar 24,5\% sedangkan sisanya sebesar 75,5\% dipengaruhi oleh faktor lain. Dengan koefisien korelasi Pada kategori “Cukup Kuat” sebesar 49\% sedangkan sisanya 51\% dipengaruhi oleh faktor lain.

\section{DAFTAR PUSTAKA}

Arikunto, Suharsimi (2013). Prosedur Penelitian. Jakarta: PT Rineka Cipta.

Hamdayama. (2015). Model dan Metode Pembelajaran Kreatif dan Berkarakter. Bogor: Ghalia Indonesia.

Rusman. (2011). Model-Model Pembelajaran. Jakarta: PT Raja Grafindo Persada. Sugiyono. (2015). Metode Penelitian Pendidikan. Bandung: Anggota Ikatan Penerbit Indonesia (IKAPI). 